\title{
Proinflammatory circulating molecules in peripheral arterial disease (Review)
}

\author{
SALVATORE S. SIGNORELLI ${ }^{1}$, MARIA C. MAZZARINO², \\ DEMETRIOS A. SPANDIDOS ${ }^{3}$ and GRAZIA MALAPONTE ${ }^{2}$ \\ Departments of ${ }^{1}$ Internal Medicine, Angiology Unit, and ${ }^{2}$ Biomedical Sciences, University of Catania, \\ Catania, Italy; ${ }^{3}$ Department of Clinical Virology, Faculty of Medicine, University of Crete, Heraklion, Greece
}

Received May 31, 2007; Accepted June 29, 2007

\begin{abstract}
Peripheral arterial disease (PAD) affects about 5\% of the elderly population in the western world. It has been reported that PAD is associated with elevated plasma levels of the inflammatory markers. The goal of this review is to describe which proinflammatory molecules may play a role in PAD development, C-reactive protein, fibrinogen, proinflammatory cytokines, adhesion molecules and matrix metalloproteinases have been reported to be involved. High serum levels of both C-reactive protein and fibrinogen have been shown to be significantly associated with increasing severity of PAD. Among cytokines, IL-6 is one of the most studied in PAD. IL-6 is well recognized for its role in the acute phase inflammatory response which is characterized by production of a variety of hepatic proteins termed acute phase proteins. It has been shown that increased serum concentrations of several markers of the acute response, including IL-6, are elevated in patients with type 2 diabetes. These patients have a two-fold risk of PAD compared to those without type 2 diabetes. The G(-174)C IL-6 polymorphism has been suggested to influence IL-6 release, and its possible influence on PAD development among individuals with type 2 diabetes is discussed in this review. Futher study of these molecules is justified as they appear to be involved in the development of PAD.
\end{abstract}

\section{Contents}

1. Introduction

2. C-reactive proteins

3. Fibrinogen

Correspondence to: Dr G. Malaponte, Department of Biomedical Sciences, University of Catania, Via Androne 83, 95124 Catania, Italy E-mail: g.malaponte@unict.it

Key words: peripheral arterial disease, C-reactive protein, fibrinogen, pro-inflammatory cytokines, adhesion molecules, matrix metalloproteinases
4. Cytokines

5. Adhesion molecules and matrix metalloproteinases

6. Conclusion

\section{Introduction}

The term peripheral arterial disease (PAD) is widely used to refer to chronic arterial disease of the legs of atherosclerotic origin. Atherosclerosis is by far the most common cause $(>90 \%)$ of arterial problems in the leg (1). PAD affects about $5 \%$ of the elderly population over 55 years in the western world (2). Several studies have demonstrated that inflammation is also involved in the development of PAD (3-9).

Previous studies have demonstrated that PAD is closely associated with elevated plasma levels of the inflammatory markers C-reactive protein (CRP) and fibrinogen $(10,11)$. Moreover, other studies have focused on the association between such proinflammatory markers and PAD in patients with diabetes and the arterial consequences of diabetes, such as PAD. Accordingly, diabetes shows a high prevalence in the general population and is a crucial risk factor for cardiac and arterial disease (12-15).

The pivotal and crucial role played by inflammation in the pathophysiology of PAD has received much attention. Based on our current knowledge, we propose that inflammatory mediators may be involved in PAD development (Fig. 1). However, inflammation may also be associated with hypercoagulability (16), and to date we know that both raised levels of markers for inflammation and a high procoagulative status have been associated with increased risk for cardiovascular disease (CVD) (17). It has been recognized that inflammation may contribute to all stages of the atherosclerotic process (18), and considerable evidence indicated that the activated haemostatic system also plays an important role in the pathophysiology of atherosclerotic vascular disease. Pathological studies of post-mortem arteries and samples obtained during reconstructive vascular surgery related the progression of atherosclerosis to the extent of fibrin deposition and its degradation products in the arterial wall (19-21). It has been suggested that serum concentrations of inflammatory proteins, such as CRP, are associated with cardiovascular risk because they reflect the severity of the 


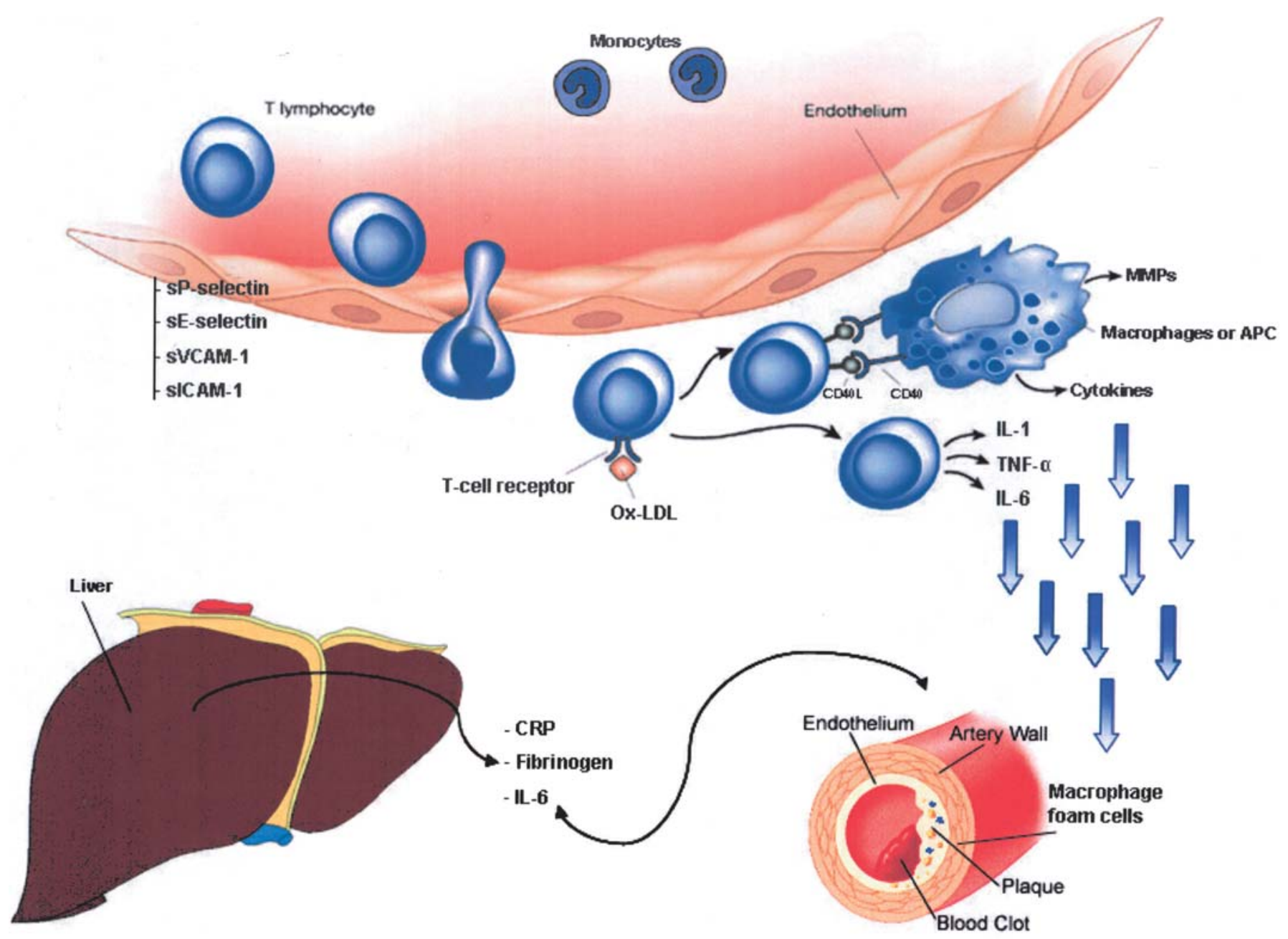

Figure 1. Inflammation process in peripheral arterial disease. This figure schematizes the migration of leukocytes through the endothelium. Once resident in the intima, the monocyte acquires characteristics of the tissue macrophage, the T cells activated by antigens such as oxidized low-density lipoprotein (Ox-LDL) produce cytokines that can influence the behaviour of other cells such as macrophages. Of note, CD40 binding to its ligand, on macrophages, may induce the expression of matrix metalloproteinases (MMPs) and proinflammatory cytokines. Crosstalk of these mediators, including those produced by liver, may contribute to inflammatory mechanisms in PAD.

atherosclerosis (22). A characteristic feature of the acute phase response is increased hepatic synthesis of a heterogeneous group of plasma proteins termed acute-phase proteins, which includes CRP, serum amyloid A (SAA), haptoglobin, and $\alpha 1$-acid glycoprotein (23).

Measurements of serum acute-phase parameters allow a sensitive quantification of the vascular inflammatory process. The vascular inflammatory process is suggested to stimulate both vascular smooth muscle cell proliferation and late neointimal growth. Vascular smooth muscle cell proliferation and hypertrophic neointimal formation at the treated segment frequently lead to stenosis of artery and also to restenosis of arterial graft $(24,25)$. Since the acute-phase response may induce damage of the vascular endothelium that is a crucial step towards the atherosclerotic plaque, plasma levels of inflammatory mediators may simply represent the extent of the atherosclerotic process. Alternatively, however, increased local or systemic inflammation due to chronic infection, chronic inflammatory disease, smoking, obesity, or impaired glucose tolerance (26-29) may precede the progression of atherosclerosis. Increased plasma levels of inflammation markers have been identified in patients with a risk of atherosclerotic diseases in many epidemiological studies. Thus, CRP (30), fibrinogen (31), D-dimer $(32,33)$ and SAA $(34,35)$ have been found to be elevated in patients with an increased risk of developing arterial consequences of atherosclerosis. It now appears that an imbalance of haemostatic factors may be involved in PAD. High blood levels of fibrinogen and homocysteine play a part and a strong association was found with PAD (1).

Elevated plasma levels of fibrinogen have been shown to predict the future risk of cardiac death and myocardial infarction in stable claudicants, and high levels were found in patients with more severe peripheral atherosclerosis $(17,36,37)$. Increased levels of haemostatic factors (e.g. D-dimer, tissue plasminogen activator antigen, plasminogen activator inhibitor, and prothrombin fragment 1,2$)$ and inflammatory markers (e.g. CRP, fibrinogen, and SAA) may be associated with functional impairment because they are sensitive measures of the burden of the atherosclerotic process of arteries in the lower leg $(18,21,22,31,32,38)$. In addition, those haemostatic components were increased in patients with PAD compared with patients without PAD $(33,38,39)$. In prospective epidemiological studies of atherosclerotic patients as well as healthy subjects, baseline 
abnormalities in several coagulation and fibrinolytic variables, including plasma fibrinogen, fibrin degradation products, coagulation factor VII and factor VIII, and tissue-type plasminogen activator have been associated with increased risk of acute thrombotic events $(21,36,37,40-43)$. In addition, increased fibrin D-dimer reflecting an overall increased coagulation has been demonstrated in patients with PAD (44).

\section{C-reactive protein}

CRP is a sensitive acute-phase reactant (45) although its function is not well defined. It binds to damaged tissue and nuclear antigens in a calcium-dependent manner, activating complement and generating proinflammatory cytokines. It is thus believed to have a proinflammatory role (46). Several prospective studies have found CRP to be a strong and independent predictor of major cardiovascular adverse events in apparently healthy men and women (47-49). It is probable that CRP itself plays a significant role in the progression of atherosclerosis (49).

In contrast to the studies involving patients with coronary artery disease (CAD) there are only a limited number of studies which have assessed CRP levels in patients with PAD. Minor elevations of CRP have been shown to be predictive of cardiovascular events in patients with coronary heart disease (50). It is now believed that CRP is not merely a marker of low-grade chronic systemic inflammation but may be actively involved in atherosclerosis as it can amplify the inflammatory response through complement activation, tissue damage and activation of endothelial cells (51). Ridker and colleagues have shown CRP levels to be a strong predictor of future cardiovascular events based on a study of 28,000 women (49). McDermott and colleagues, have shown that CRP was not associated with ankle-brachial pressure index in patients without a history of cardiac or cerebrovascular disease (33).

Many studies indicated that blood coagulation cascade is activated in patients with PAD (47). The direct effect of fibrinogen on atherosclerosis is through several processes, such as: a) its effect on clot structure, since increased plasma fibrinogen levels result in fibrin matrices with a tight structure that are difficult to lyse; and b) fibrinogen induces chemotaxis of smooth muscle cells and monocytes/macrophages (52).

\section{Fibrinogen}

Blood viscosity and its major determinants (plasma viscosity, haematocrit and fibrinogen) have been shown to be significantly associated with increasing severity of PAD, and with early evidence of atherosclerosis (measured by carotid intimamedia thickness) (53), and studies have analyzed the role of coagulative factors in diabetics with PAD (54-59). Fibrinogen has been implicated in the increased risk of PAD in diabetic populations (54-61).

\section{Cytokines}

Cytokines, such as interleukin (IL)-6 and tumor necrosis factor (TNF)- $\alpha$, are soluble polypeptides acting as important humoral regulators in immunoregulation, hematopoiesis, and the inflammatory cascade $(62,63)$. CRP is an end-product of inflammation whose synthesis by the liver is stimulated by cytokines (64). Circulating cytokine receptors may provide additional information in chronic inflammatory processes because they generally have a longer half-life than the cytokines themselves and, therefore, show more constant levels over time $(65,66)$.

Interleukin-6. Among cytokines, IL-6 is one of the most studied in PAD. IL-6 contributes to a myriad of physiologic and pathophysiologic processes (67). Because of the large scope of its effects, the cellular and molecular biology of IL-6 has been explored by a variety of investigators representing a great number of basic biological and medical fields. IL-6 is well recognized for its role in the acute-phase inflammatory response which is characterized by production of a variety of hepatic proteins termed acute-phase proteins (e.g., Creactive protein, serum amyloid $\mathrm{A}$, fibrinogen, complement, $\alpha 1$-antitrypsin) (68).

G(-174)C IL-6 polymorphism. It has been shown that increased serum concentrations of several markers of the acute response, including IL-6, are elevated in patients with type 2 diabetes $(69,70)$. Individuals with type 2 diabetes have a two-fold risk of PAD compared to those without type 2 diabetes (71). The G(-174)C IL-6 polymorphism has been suggested to influence IL-6 release (72). Recently our group determined whether the G(-174)C IL-6 polymorphism may influence development of PAD among individuals with type 2 diabetes. This possibility was investigated by comparing the distribution of G(-174)C genotypes among subjects with type 2 diabetes and PAD to that of subjects with type 2 diabetes without PAD. The data reported by Libra et al (73) showed that the GG genotype was more frequently present among diabetics with PAD than those without PAD. This finding suggests that individuals with type 2 diabetes and the GG genotype may develop PAD more often than those with GC or CC genotypes.

Previous studies comparing plasma IL-6 levels to G(-174)C genotype have yielded conflicting results. Some investigators detected increased plasma IL-6 levels among those with the GG genotype while others observed increased plasma IL-6 levels among those with the CC genotype (72,74-76). Plasma IL-6 levels have also been reported to be independent of the $\mathrm{G}(-174) \mathrm{C}$ genotype $(77,78)$. Libra et al indicate that both diabetics with and without PAD with the GG genotype have higher mean plasma IL-6 levels than those with GC or CC genotypes. An analysis of plasma levels of IL-6, fibrinogen, and CRP among abdominal aortic aneurysm patients reveals that only IL-6 plasma levels vary among patients with different $\mathrm{G}(-174) \mathrm{C}$ genotypes (79). In contrast, the GG genotype is associated with increased mean plasma levels of IL-6 as well as fibrinogen and CRP in the study conducted by Libra et al. Therefore, it is possible that the GG genotype facilitates increased IL- 6 release among individuals with type 2 diabetes that then causes increased release of fibrinogen and CRP. This possibility is further supported by the observation that plasma levels of IL-6, fibrinogen, and CRP among PAD-positive subjects were each correlated with one another (73). Thus, the GG genotype promotes development of PAD among individuals with type 2 diabetes by inducing increased release 
of IL-6. Elevated release of IL-6 into the bloodstream in those with the GG genotype causes increased release of fibrinogen and CRP. These findings are consistent with previous studies that have documented increased incidence of CVD among individuals with the GG genotype compared to those with the CC genotype $(75,76,80,81)$. However, other studies have associated CVD with the CC genotype instead of the GG genotype $(79,82-84)$. The conflicting results that have been reported suggest that there may be a complex relationship between G(-174)C genotype and development of CVD. The relationship between G(-174)C genotype and PAD development may differ among individuals with different clinical characteristics.

\section{Adhesion molecules and matrix metalloproteinases}

The role of proinflammatory circulating molecules in vascular disease is clear (85-87); activated leukocytes emigrate, adhere to the endothelial wall and migrate through the arterial wall, resulting in the transfer of macrophages rich in oxidized lipoproteins that trigger the onset of atherosclerotic plaque formation (88-91). In contrast, few studies have been conducted on the response of adhesion molecules in patients with PAD (92-100). Our previous studies have shown higher levels of soluble inflammatory mediators and adhesion molecules such as E-selectin, L-selectin, P-selectin, VCAM-1 and ICAM-I in patients with PAD than in controls. Blood samples were also analyzed at rest and after maximal treadmill test (101). The molecules analyzed were higher both at rest in PAD than in controls, these increased in both patients and controls after a maximal treadmill test but a significant difference was found comparing the after-test serum levels between PAD and controls. This suggests a close relationship between physical stress and activation of white blood cells that in turn are able to release the adhesion molecules into the bloodstream. Therefore, it is suggested that increased serum concentrations of both cytokines and adhesion molecules can determine further changes in leukocytes (rolling, adhesion) and lead to endothelial damage. Atherosclerosis is also characterized by degeneration of the extracellular matrix (ECM) proteins. Degradation occurs as a consequence of complex interactions between genetic factors, inflammatory cytokines, matrix metalloproteinases (MMPs), tissue inhibitors of MMPs (TIMPs), and others. The resulting phenotype is dissolution and fragmentation of collagen and elastin, leading to expansion of the vessel wall. MMPs are a family of $\mathrm{Zn}^{2+}$-dependent enzymes that catalyze the proteolysis of many connective tissue proteins of the ECM such as collagen, gelatin, fibronectin, laminin, elastin, and proteoglycans $(102,103)$. Other MMP substrates are not components of the ECM. MMPs have been implicated in the degradation of myelin basic protein (104), and interleukin-1ß (105), as well as proteolytic processing of tumor necrosis factor- $\alpha$ (106). MMPs are secreted as proenzymes by many cell types (107), including leukocytes, macrophages, astrocytes, neurons, and microglia, and are widely distributed in tissues and biological fluids such as blood and urine (108). They are involved in many physiological processes, including tissue remodeling during development and platelet aggregation (109). MMPs also have role in pathophysiological processes such as inflammation, tissue repair, myocardial injury, vascular diseases, tumor invasion, and metastasis (110-112). Activity of MMPs is negatively regulated by tissue inhibitors of matrix metalloproteinases (TIMPs) (79). The in vivo balance between MMPs and TIMPs dictates the level of MMP activity (113). Deterioration of MMP regulation contributes to the development of arterial lesions, in part, by facilitating monocyte invasion (114).

Physiologically, extracellular matrix proteins maintain the integrity of the vessel wall. In fact, degradation of these proteins is minimal because they are expressed at low levels and in inactive forms (115). The activation of MMPs requires the removal of an amino-terminal sequence by plasmin and the plasmin-generating enzymes tissue-type plasminogen activator and urokinase-type plasminogen activator, which are minimally expressed in the normal vessel wall. In addition, activated inflammatory cells, which are the main sources of collagenolytic and elastinolytic proteinases, are also absent. Furthermore, expressed TIMPs neutralize the proteolytic activities of MMPs. Collectively, these processes maintain the integrity of the extracellular matrix proteins and the vessel wall.

Gelatin zymography studies have shown that MMPs, especially MMP-2 (72-kDa gelatinase A) $(116,117)$ and MMP-9 (92-kDa gelatinase B) (118), are involved in remodeling processes associated with atherogenesis $(119,120)$. MMPs are synthesized in atheromatous plaques (121) and elevated levels are present in rupture-prone shoulder regions of arterial vessels (122). Increased MMP activity has also been correlated with CVD $(123,124)$.

Several studies have investigated the potential involvement of MMPs in atherosclerosis. For example, expression of MMP-2 was shown to be increased within atherosclerotic plaques $(125,126)$. Other studies have implied that expression and activity of MMPs may be increased among type 2 diabetes (112,127-129). Death et al showed that exposure to a high concentration of glucose induced increased expression and activity of MMP-1 and MMP-2 in endothelial cells and MMP-9 in macrophages (112). Plasma levels of MMP-9 and other markers of inflammation were decreased in type 2 diabetics by treatment with rosiglitazone, recently introduced for the management of diabetes $(127,128)$. Portik-Dobos et al have reported that MMP-9 levels are lower in blood vessels isolated from type 2 diabetics than from normal individuals (129). Data from our studies have indicated that MMP-9 is released from blood vessels into the bloodstream in patients with type 2 diabetes and PAD to a greater extent than in healthy individuals, which may contribute to increased chronic local inflammation of blood vessels among type 2 diabetics. Additionally, the endothelium in blood vessels from diabetics may activate MMP-producing cells in the circulation (130).

\section{Conclusion}

This article describes the involvement of pro-inflammatory molecules in the pathophysiology of PAD both for atherosclerotic and diabetic patients. More inflammatory markers were found in the serum of patients with PAD and we speculate that these markers could be considered as relevant in monitoring the course of the disease. Accordingly, we must consider that activated white blood cells and endothelial 
dysfunction, and a lack of fibrinolytic activity of endothelium membrane and consequently presence of coagulative status can play a crucial role in worsening the blood supply towards a critical reduction, especially in microcirculation, and overall these factors lead to critical limb ischemia as a severe clinical haemodynamic situation in the lower limbs. Additionally, proving a pathogenic role of cytokines could aid the development of novel therapeutic approaches for the prevention and also for the management of PAD by negating the action of endogenous cytokines. This is noteworthy considering that all vasoactive drugs usually given for treatment of PAD were judged unable to fulfil all the targets of the therapy (131). However, the role of the MMP family in PAD development has been studied and, therefore, we should consider how this knowledge may also influence the treatment of PAD.

\section{References}

1. Cimminiello C: PAD. Epidemiology and pathophysiology. Thromb Res 106: V295-V301, 2002.

2. Fowkes FG, Housley E, Cawood EH, Macintyre CC, Ruckley CV and Prescott RJ: Edinburgh Artery Study: prevalence of asymptomatic and symptomatic peripheral arterial disease in the general population. Int J Epidemiol 20: 384-392, 1991.

3. Brevetti G, Martone VD, de Cristofaro T, et al: High levels of adhesion molecules are associated with impaired endotheliumdependent vasodilatation in patients with peripheral arterial disease. Thromb Haemost 85: 63-66, 2001

4. Beckman JA, Preis O, Ridker PM and Gerhard-Herman M: Comparison of usefulness of inflammatory markers in patients with versus without peripheral arterial disease in predicting adverse cardiovascular outcomes (myocardial infarction, stroke, and death). Am J Cardiol 96: 1374-1378, 2005.

5. McDermott MM, Guralnik JM, Greenland P, et al: Inflammatory and thrombotic blood markers and walking-related disability in men and women with and without peripheral arterial disease. J Am Geriatr Soc 52: 1888-1894, 2004.

6. Nylaende M, Kroese A, Stranden E, et al: Markers of vascular inflammation are associated with the extent of atherosclerosis assessed as angiographic score and treadmill walking distances in patients with peripheral arterial occlusive disease. Vasc Med 11: 21-28, 2006 .

7. McDermott MM, Guralnik JM, Corsi A, Albay M, Macchi C, Bandinelli S and Ferrucci L: Patterns of inflammation associated with peripheral arterial disease: In the CHIANTI study. Am Heart J 150: 276-281, 2005.

8. Videm V, Wiseth R, Gunnes S, Madsen HO and Garred P: Multiple inflammatory markers in patients with significant coronary artery disease. Int J Cardiol 118: 81-87, 2007.

9. Apostolakis S, Papadakis EG, Krambovitis E and Spandidos DA: Chemokines in vascular pathology (Review). Int J Mol Med 17: 691-701, 2006.

10. Rossi E, Biasucci LM, Citterio F, et al: Risk of myocardial infarction and angina in patients with severe peripheral vascular disease: predictive role of C-reactive protein. Circulation 105: 800-803, 2002.

11. Violi F, Criqui M, Longoni A and Castiglioni C: Relation between risk factors and cardiovascular complications in patients with peripheral vascular disease. Results from the A.D.E.P. study. Atherosclerosis 120: 25-35, 1996.

12. Gordon T and Kannel WB: Predisposition to atherosclerosis in the head, heart, and legs. The Framingham study. JAMA 221: 661-666, 1972.

13. Fowkes FG, Housley E, Riemersma RA, Macintyre CC, Cawood EH, Prescott RJ and Ruckley CV: Smoking, lipids, glucose intolerance, and blood pressure as risk factors for peripheral atherosclerosis compared with ischemic heart disease in the Edinburgh Artery Study. Am J Epidemiol 135: 331-340, 1992.

14. Adler AI, Stevens RJ, Neil A, Stratton IM, Boulton AJ and Holman RR: UKPDS 59: hyperglycemia and other potentially modifiable risk factors for peripheral vascular disease in type 2 diabetes. Diabetes Care 25: 894-899, 2002.
15. Khaw KT, Wareham N, Luben R, Bingham S, Oakes S, Welch A and Day N: Glycated haemoglobin, diabetes, and mortality in men in Norfolk cohort of european prospective investigation of cancer and nutrition (EPIC-Norfolk). BMJ 322: 15-18, 2001.

16. Esmon CT: Does inflammation contribute to thrombotic events? Haemostasis 2: 34-40, 2000.

17. Thor M, Yu A and Swedenborg J: Markers of inflammation and hypercoagulability in diabetic and nondiabetic patients with lower extremity ischemia. Thromb Res 105: 379-383, 2002.

18. Ross R: Atherosclerosis - an inflammatory disease. N Engl J Med 340: 115-126, 1999.

19. Falk E and Fernandez-Ortiz A: Role of thrombosis in atherosclerosis and its complications. Am J Cardiol 75: 3B-11B, 1995.

20. Fuster V, Fallon JT, Badimon JJ and Nemerson Y: The unstable atherosclerotic plaque: clinical significance and therapeutic intervention. Thromb Haemost 78: 247-255, 1997.

21. Komarov A, Panchenko E, Dobrovolsky A, et al: D-dimer and platelet aggregability are related to thrombotic events in patients with peripheral arterial occlusive disease. Eur Heart J 23: 1309-1316, 2002.

22. De Maat MP, Bladbjerg EM, Drivsholm T, Borch-Johnsen K, Moller L and Jespersen J: Inflammation, thrombosis and atherosclerosis: results of the Glostrup study. J Thromb Haemost 1: 950-957, 2003.

23. Sasaki K, Ma Z, Khatlani TS, Okuda M, Inokuma H and Onishi T: Evaluation of feline serum amyloid A (SAA) as an inflammatory marker. J Vet Med Sci 65: 545-548, 2003.

24. Kornowski R, Hong MK, Tio FO, Bramwell O, Wu H and Leon MB: In-stent restenosis: contributions of inflammatory responses and arterial injury to neointimal hyperplasia. J Am Coll Cardiol 31: 224-230, 1998.

25. Yutani C, Ishibashi-Ueda H, Suzuki T and Kojima A: Histologic evidence of foreign body granulation tissue and de novo lesions in patients with coronary stent restenosis. Cardiology 92: 171-177, 1999.

26. Yudkin JS, Stehouwer CD, Emeis JJ and Coppack SW: C-reactive protein in healthy subjects: associations with obesity, insulin resistance, and endothelial dysfunction: a potential role for cytokines originating from adipose tissue? Arterioscler Thromb Vasc Biol 19: 972-978, 1999.

27. Das I: Raised C-reactive protein levels in serum from smokers. Clin Chim Acta 153: 9-13, 1985.

28. Young B, Gleeson M and Cripps AW: C-reactive protein: a critical review. Pathology 23: 118-124, 1991.

29. Van der Meer IM, de Maat MP, Bots ML, et al: Inflammatory mediators and cell adhesion molecules as indicators of severity of atherosclerosis: the Rotterdam Study. Arterioscler Thromb Vasc Biol 22: 838-842, 2002.

30. Ridker PM, Cushman M, Stampfer MJ, Tracy RP and Hennekens CH: Inflammation, aspirin, and the risk of cardiovascular disease in apparently healthy men. N Engl J Med 336: 973-979, 1997. Erratum in: N Engl J Med 337: 356, 1997.

31. Smith FB, Lee AJ, Hau CM, Rumley A, Lowe GD and Fowkes FG: Plasma fibrinogen, haemostatic factors and prediction of peripheral arterial disease in the Edinburgh Artery Study. Blood Coagul Fibrinolysis 11: 43-50, 2000.

32. McDermott MM, Greenland P, Green D, et al: D-dimer, inflammatory markers, and lower extremity functioning in patients with and without peripheral arterial disease. Circulation 107: 3191-3198, 2003

33. McDermott MM, Green D, Greenland P, et al: Relation of levels of hemostatic factors and inflammatory markers to the ankle brachial index. Am J Cardiol 92: 194-199, 2003.

34. Liuzzo G, Biasucci LM, Gallimore JR, Grillo RL, Rebuzzi AG, Pepys MB and Maseri A: The prognostic value of C-reactive protein and serum amyloid a protein in severe unstable angina. N Engl J Med 331: 417-424, 1994.

35. Katayama T, Nakashima H, Yonekura T, Honda Y, Suzuki S and Yano K: Significance of acute-phase inflammatory reactants as an indicator of prognosis after acute myocardial infarction: which is the most useful predictor? J Cardiol 42: 49-56, 2003.

36. Banerjee AK, Pearson J, Gilliland EL, Goss D, Lewis JD, Stirling Y and Meade TW: A six year prospective study of fibrinogen and other risk factors associated with mortality in stable claudicants.Thromb Haemost 68: 261-263, 1992.

37. Lassila R, Peltonen S, Lepantalo M, Saarinen O, Kauhanen P and Manninen V: Severity of peripheral atherosclerosis is associated with fibrinogen and degradation of cross-linked fibrin. Arterioscler Thromb 13: 1738-1742, 1993. 
38. Lee AJ, Fowkes FG, Lowe GD and Rumley A: Fibrin D-dimer, haemostatic factors and peripheral arterial disease. Thromb Haemost 74: 828-832, 1995.

39. Van der Born JG, Bots Ml, Haverkate F, et al: Activation products of the haemostatic system in coronary, cerebrovascular, and peripheral arterial disease. Thromb Haemost 85: 234-239, 2001.

40. Ridker PM, Hennekens CH, Cerskus A and Stampfer MJ: Plasma concentration of cross-linked fibrin degradation product (D-dimer) and the risk of future myocardial infarction among apparently healthy men. Circulation 90: 2236-2240, 1994.

41. Fowkes FG, Lowe GD, Housley E, et al: Cross-linked fibrin degradation products, progression of peripheral arterial disease, and risk of coronary heart disease. Lancet 342: 84-86, 1993.

42. Jansson JH, Olofsson BO and Nilsson TK: Predictive value of tissue plasminogen activator mass concentration on long-term mortality in patients with coronary artery disease. A 7-year follow-up. Circulation 88: 2030-2034, 1993.

43. Meade TW, Cooper JA, Stirling Y, Howarth DJ, Ruddock V and Miller GJ: Factor VIII, ABO blood group and the incidence of ischaemic heart disease. Br J Haematol 88: 601-607, 1994.

44. Cortellaro M, Cofrancesco E, Boschetti C, et al: Association of increased fibrin turnover and defective fibrinolytic capacity with leg atherosclerosis. The PLAT Group. Thromb Haemost 72: 292-296, 199489.

45. Chambers RE, Hutton CW, Dieppe PA and Whicher JT: Comparative study of $\mathrm{C}$ reactive protein and serum amyloid $\mathrm{A}$ protein in experimental inflammation. Ann Rheum Dis 50: 677-679, 1991.

46. Du Clos TW: Function of C-reactive protein. Ann Med 32: 274-278, 2000

47. Rifai N and Ridker PM: High-sensitivity C-reactive protein: a novel and promising marker of coronary heart disease. Clin Chem 47: 403-411, 2001.

48. Ridker PM, Cushman M, Stampfer MJ, Tracy RP and Hennekens CH: Plasma concentration of C-reactive protein and risk of developing peripheral vascular disease. Circulation 97: 425-428, 1998.

49. Ridker PM, Hennekens CH, Buring JE and Rifai N: C-reactive protein and other markers of inflammation in the prediction of cardiovascular disease in women. N Engl J Med 342: 836-843, 2000.

50. Erren M, Reinecke H, Junker R, et al: Systemic inflammatory parameters in patients with atherosclerosis of the coronary and peripheral arteries. Arterioscler Thromb Vasc Biol 19: 2355-2363, 1999.

51. Bataille R and Klein B: C-reactive protein levels as a direct indicator of interleukin-6 levels in humans in vivo. Arthritis Rheum 35: 982-984, 1992.

52. Mosesson MW, Siebenlist KR and Meh DA: The structure and biological features of fibrinogen and fibrin. Ann NY Acad Sci 936: 11-30, 2001.

53. Lowe GD, Fowkes FG, Dawes J, Donnan PT, Lennie SE and Housley E: Blood viscosity, fibrinogen, and activation of coagulation and leukocytes in peripheral arterial disease and the normal population in the Edinburgh Artery Study. Circulation 87: 1915-1920, 1993.

54. Breddin HK, Krzywanek HJ, Althoff P, et al: Spontaneous platelet aggregation and coagulation parameters as risk factors for arterial occlusions in diabetics. Results of the PARD-study. Int Angiol 5: 181-195, 1986.

55. Maser RE, Wolfson SK Jr, Ellis D, et al: Cardiovascular disease and arterial calcification in insulin-dependent diabetes mellitus: interrelations and risk factor profiles. Pittsburgh Epidemiology of Diabetes Complications Study-V. Arterioscler Thromb 11: 958-965, 1991.

56. Bruno G, Cavallo-Perin P, Bargero G, Borra M, D'Errico N and Pagano G: Association of fibrinogen with glycemic control and albumin excretion rate in patients with non-insulin-dependent diabetes mellitus. Ann Intern Med 125: 653-657, 1996.

57. Bell DS: Diabetes mellitus and coronary artery disease. J Cardiovasc Risk 4: 83-90, 1997.

58. Tkac I and Molcanyiova A: Fibrinogen and albuminuria are related to the presence and severity of peripheral arterial disease in women with type 2 diabetes mellitus. Angiology 48: 715-719, 1997.

59. Lee AJ, Mowbray PI, Lowe GD, Rumley A, Fowkes FG and Allan PL: Blood viscosity and elevated carotid intima-media thickness in men and women: the Edinburgh Artery Study. Circulation 97: 1467-1473, 1998.
60. Kannel WB, D'Agostino RB, Wilson PW, Belanger AJ and Gagnon DR: Diabetes, fibrinogen, and risk of cardiovascular disease: the Framingham experience. Am Heart J 120: 672-676, 1990.

61. Tkac I, Tkacova R, Takac M and Lazur J: Hematologic changes in type 2 diabetic patients with various localizations of peripheral vascular disease. Vasa 21: 360-364, 1992.

62. Van Stick J: Interleukin-6: an overview. Annu Rev Immunol 8: 253-278, 1990.

63. Beutler BA, Milsark IW and Cerami A: Cachectin/tumor necrosis factor: production, distribution, and metabolic fate in vivo. J Immunol 135: 3972-3977, 1985.

64. Mendall MA, Patel P, Asante M, et al: Relation of serum cytokine concentrations to cardiovascular risk factors and coronary heart disease. Heart 78: 273-277, 1997.

65. Elkind MS, Cheng J, Boden-Albala B, et al: Tumor necrosis factor receptor levels are associated with carotid atherosclerosis. Stroke 33: 31-37, 2002.

66. Dibbs Z, Thornby J, White BG and Mann DL: Natural variability of circulating levels of cytokines and cytokine receptors in patients with heart failure: implications for clinical trials. J Am Coll Cardiol 33: 1935-1942, 1999.

67. Akira S, Taga T and Kishimoto T: Interleukin-6 in biology and medicine. Adv Immunol 54: 1-78, 1993.

68. Sehgal PB, Greininger G and Tosato G: Acute phase and immune responses: Interleukin-6. Ann NY Acad Sci 557: 1-583, 1989.

69. Kado S, Nagase $T$ and Nagata N: Circulating levels of interleukin-6, its soluble receptor and interleukin-6/interleukin-6 receptor complexes in patients with type 2 diabetes mellitus. Acta Diabetol 36: 67-72, 1999.

70. Yu HI, Sheu WH, Song YM, Liu HC, Lee WJ and Chen YT: C-reactive protein and risk factors for peripheral vascular disease in subjects with Type 2 diabetes mellitus. Diabet Med 21: 336-341, 2004.

71. Walters DP, Gatling W, Mullee MA and Hill RD: The prevalence, detection, and epidemiological correlates of peripheral vascular disease: a comparison of diabetic and non-diabetic subjects in an English community. Diabet Med 9: 710-715, 1992.

72. Fishman D, Faulds G, Jeffery R, Mohamed-Ali V, Yudkin JS, Humphries $S$ and Woo P: The effect of novel polymorphisms in the interleukin-6 (IL-6) gene on IL-6 transcription and plasma IL-6 levels, and an association with systemic-onset juvenile chronic arthritis. J Clin Invest 102: 1369-1376, 1998.

73. Libra M, Signorelli SS, Bevelacqua Y, et al: Analysis of G(-174)C IL-6 polymorphism and plasma concentrations of inflammatory markers in patients with type 2 diabetes and peripheral arterial disease. J Clin Pathol 59: 211-215, 2006.

74. Jones KG, Brull DJ, Brown LC, Sian M, Greenhalgh RM, Humphries SE and Powell JT: Interleukin-6 (IL-6) and the prognosis of abdominal aortic aneurysms. Circulation 103: 2260-2265, 2001.

75. Burzotta F, Iacoviello L, Di Castelnuovo A, et al: Relation of the $-174 \mathrm{G} / \mathrm{C}$ polymorphism of interleukin- 6 to interleukin- 6 plasma levels and to length of hospitalization after surgical coronary revascularization. Am J Cardiol 1588: 1125-1128, 2001.

76. Giacconi R, Cipriano C, Albanese F, et al: The $-174 \mathrm{G} / \mathrm{C}$ polymorphism of IL-6 is useful to screen old subjects at risk for atherosclerosis or to reach successful ageing. Exp Gerontol 39: 621-628, 2004.

77. Rauramaa R, Vaisanen SB, Luong LA, et al: Stromelysin-1 and interleukin-6 gene promoter polymorphisms are determinants of asymptomatic carotid artery atherosclerosis. Arterioscler Thromb Vasc Biol 20: 2657-2662, 2000.

78. Nauck M, Winkelmann BR, Hoffmann MM, Bohm BO, Wieland $\mathrm{H}$ and Marz W: The interleukin-6 G(-174)C promoter polymorphism in the LURIC cohort: no association with plasma interleukin-6, coronary artery disease, and myocardial infarction. J Mol Med 80: 507-513, 2002

79. Brew K, Dinakarpandian D and Nagase H: Tissue inhibitors of metalloproteinases: evolution, structure and function. Biochim Biophys Acta 1477: 267-283, 2000.

80. Flex A, Gaetani E, Pola R, et al: The $-174 \mathrm{G} / \mathrm{C}$ polymorphism of the interleukin- 6 gene promoter is associated with peripheral artery occlusive disease. Eur J Vasc Endovasc Surg 24: 264-268, 2002.

81. Greisenegger S, Endler G, Haering D, Schillinger M, Lang W, Lalouschek W and Mannhalter C: The (-174) G/C polymorphism in the interleukin- 6 gene is associated with the severity of acute cerebrovascular events. Thromb Res 110: 181-186, 2003. 
82.Chapman CM, Beilby JP, Humphries SE, Palmer LJ, Thompson PL and Hung J: Association of an allelic variant of interleukin-6 with subclinical carotid atherosclerosis in an Australian community population. Eur Heart J 24: 1494-1499, 2003.

83. Exner M, Schillinger M, Minar E, et al: Interleukin-6 promoter genotype and restenosis after femoropopliteal balloon angioplasty: initial observations. Radiology 231: 839-844, 2004.

84. Jenny NS, Tracy RP, Ogg MS, et al: In the elderly, interleukin-6 plasma levels and the $-174 \mathrm{G}>\mathrm{C}$ polymorphism are associated with the development of cardiovascular disease. Arterioscler Thromb Vasc Biol 22: 2066-2071, 2002.

85. Springer TA: Traffic signals for lymphocyte recirculation and leukocyte emigration: the multistep paradigm. Cell 76: 301-314, 1994

86. Gearing AJ and Newman W: Circulating adhesion molecules in disease. Immunol Today 14: 506-512, 1993.

87. O'Brien KD, McDonald TO, Chait A, Allen MD and Alpers CE: Neovascular expression of E-selectin, intercellular adhesion molecule-1, and vascular cell adhesion molecule-1 in human atherosclerosis and their relation to intimal leukocyte content. Circulation 93: 672-682, 1996.

88. Ernst E, Hammerschmidt DE, Bagge U, Matrai A and Dormandy JA: Leukocytes and the risk of ischemic diseases. JAMA 257: 2318-2324, 1987.

89. Mayrovitz HN and Rubin R: Leukocyte distribution to arteriolar branches: dependence on microvascular blood flow. Microvasc Res 29: 282-294, 1985.

90. Steinberg D and Lewis A: Conner Memorial Lecture: Oxidative modification of LDL and atherogenesis. Circulation 95: 1062-1071, 1997.

91. Gryglewski RJ, Palmer RM and Moncada S: Superoxide anion is involved in the breakdown of endothelium-derived vascular relaxing factor. Nature 320: 454-456, 1986.

92. Cimminiello C, Arpaia G, Toschi V, Rossi F, Aloisio M, Motta A and Bonfardeci G: Plasma levels of tumor necrosis factor and endothelial response in patients with chronic arterial obstructive disease or Raynaud's phenomenon. Angiology 45: 1015-1022, 1994.

93. Neumann FJ, Waas W, Diehm C, et al: Activation and decreased deformability of neutrophils after intermittent claudication. Circulation 82: 922-929, 1990

94. Khaira HS, Nash GB, Bahra PS, Sanghera K, Gosling P, Crow AJ and Shearman CP: Thromboxane and neutrophil changes following intermittent claudication suggest ischaemiareperfusion injury. Eur J Vasc Endovasc Surg 10: 31-35, 1995.

95. Fiotti N, Giansante C, Ponte E, et al: Atherosclerosis and inflammation. Patterns of cytokine regulation in patients with peripheral arterial disease. Atherosclerosis 145: 51-60, 1999.

96. Kirk G, Hickman P, McLaren M, Stonebridge PA and Belch JJ: Interleukin-8 (IL-8) may contribute to the activation of neutrophils in patients with peripheral arterial occlusive disease (PAOD). Eur J Vasc Endovasc Surg 1: 434-438, 1999.

97. Brevetti G, Silvestro A, Di Giacomo S, Bucur R, Di Donato A, Schiano V and Scopacasa F: Endothelial dysfunction in peripheral arterial disease is related to increase in plasma markers of inflammation and severity of peripheral circulatory impairment but not to classic risk factors and atherosclerotic burden. J Vasc Surg 38: 374-379, 2003.

98. Brevetti G, De Caterina M, Martone VD, et al: Exercise increases soluble adhesion molecules ICAM-1 and VCAM-1 in patients with intermittent claudication. Clin Hemorheol Microcirc 24: 193-199, 2001.

99. Ciuffetti G, Mannarino E, Pasqualini L, Mercuri M, Lennie SE and Lowe GD: The hemorheological role of cellular factors in peripheral vascular disease. Vasa 17: 168-170, 1988.

100. Signorelli SS, Neri S, Di Pino L, et al: Effect of PLC on functional parameters and oxidative profile in type 2 diabetesassociated PAD. Diabetes Res Clin Pract 72: 231-237, 2006.

101. Signorelli SS, Mazzarino MC, Di Pino L, et al: High circulating levels of cytokines (IL-6 and TNFalpha), adhesion molecules (VCAM-1 and ICAM-1) and selectins in patients with peripheral arterial disease at rest and after a treadmill test. Vasc Med 8: 15-19, 2003.

102. Van den Steen PE, Opdenakker G, Wormald MR, Dwek RA and Rudd PM: Matrix remodelling enzymes, the protease cascade and glycosylation. Biochim Biophys Acta 1528: 61-73, 2001.

103. Borkakoti N: Structural studies of matrix metalloproteinases. J Mol Med 78: 261-268, 2000.
104.Gijbels K, Proost P, Masure S, Carton H, Billiau A and Opdenakker G: Gelatinase B is present in the cerebrospinal fluid during experimental autoimmune encephalomyelitis and cleaves myelin basic protein. J Neurosci Res 36: 432-440, 1993.

105. Ito A, Mukaiyama A, Itoh Y, et al: Degradation of interleukin 1 beta by matrix metalloproteinases. J Biol Chem 271: 14657-14660, 1996.

106. Gearing AJ, Beckett P, Christodoulou M, et al: Processing of tumour necrosis factor-alpha precursor by metalloproteinases. Nature 370: 555-557, 1994.

107. Bartholome EJ, Van Aelst I, Koyen E, Kiss R, Willems F, Goldman $\mathrm{M}$ and Opdenakker G: Human monocyte-derived dendritic cells produce bioactive gelatinase B: inhibition by IFN-beta. J Interferon Cytokine Res 21: 495-501, 2001.

108. Lein M, Nowak L, Jung K, Koenig F, Lichtinghagen R, Schnorr D and Loening SA: Analytical aspects regarding the measurement of metalloproteinases and their inhibitors in blood. Clin Biochem 30: 491-496, 1997.

109. Sawicki G, Sanders EJ, Salas E, Wozniak M, Rodrigo J and Radomski MW: Localization and translocation of MMP-2 during aggregation of human platelets. Thromb Haemost 80 : 836-839, 1998.

110. Creemers EE, Cleutjens JP, Smits JF and Daemen MJ: Matrix metalloproteinase inhibition after myocardial infarction: a new approach to prevent heart failure? Circ Res 89: 201-210, 2001.

111. Itoh Y and Nagase H: Matrix metalloproteinases in cancer. Essays Biochem 38: 21-36, 2002.

112. Death AK, Fisher EJ, McGrath KC and Yue DK: High glucose alters matrix metalloproteinase expression in two key vascular cells: potential impact on atherosclerosis in diabetes. Atherosclerosis 168: 263-269, 2003.

113. Visse R and Nagase H: Matrix metalloproteinases and tissue inhibitors of metalloproteinases: structure, function, and biochemistry. Circ Res 92: 827-839, 2003.

114. Dollery CM, McEwan JR and Henney AM: Matrix metalloproteinases and cardiovascular disease. Circ Res 77: 863-868, 1995.

115. Curci JA, Liao S, Huffman MD, Shapiro SD and Thompson RW: Expression and localization of macrophage elastase (matrix metalloproteinase-12) in abdominal aortic aneurysms. J Clin Invest 102: 1900-1910, 1998.

116. Gohlke U, Gomis-Ruth FX, Crabbe T, Murphy G, Docherty AJ and Bode W: The C-terminal (haemopexin-like) domain structure of human gelatinase A (MMP2): structural implications for its function. FEBS Lett 378: 126-130, 1996.

117. Asanuma K, Magid R, Johnson C, Nerem RM and Galis ZS: Uniaxial strain upregulates matrix-degrading enzymes produced by human vascular smooth muscle cells. Am J Physiol Heart Circ Physiol 284: H1778-H1784, 2003.

118. Opdenakker G, Van den Steen PE, Dubois B, et al: Gelatinase $\mathrm{B}$ functions as regulator and effector in leukocyte biology. J Leukoc Biol 69: 851-859, 2001.

119. Galis ZS, Johnson C, Godin D, Magid R, Shipley JM, Senior RM and Ivan E: Targeted disruption of the matrix metalloproteinase-9 gene impairs smooth muscle cell migration and geometrical arterial remodeling. Circ Res 91: 852-859, 2002.

120. Galis ZS and Khatri JJ: Matrix metalloproteinases in vascular remodelling and atherogenesis: the good, the bad, and the ugly. Circ Res 90: 251-262, 2002.

121. Galis ZS, Sukhova GK, Lark MW and Libby P: Increased expression of matrix metalloproteinases and matrix degrading activity in vulnerable regions of human atherosclerotic plaques. J Clin Invest 94: 2493-2503, 1994.

122. Shah PK and Galis ZS: Matrix metalloproteinase hypothesis of plaque rupture: players keep piling up but questions remain. Circulation 104: 1878-1880, 2001.

123. Gao CQ, Sawicki G, Suarez-Pinzon WL, Csont T, Wozniak M, Ferdinandy P and Schulz R: Matrix metalloproteinase-2 mediates cytokine-induced myocardial contractile dysfunction. Cardiovasc Res 57: 426-433, 2003.

124. Shah PK, Falk E, Badimon JJ, et al: Human monocyte-derived macrophages induce collagen breakdown in fibrous caps of atherosclerotic plaques. Potential role of matrix-degrading metalloproteinases and implications for plaque rupture. Circulation 92: 1565-1569, 1995.

125.Loftus IM, Naylor AR, Bell PR and Thompson MM: Plasma MMP-9 - a marker of carotid plaque instability. Eur J Vasc Endovasc Surg 21: 17-21, 2001. 
126. Loftus IM, Naylor AR, Goodall S, Crowther M, Jones L, Bell PR and Thompson MM: Increased matrix metalloproteinase-9 activity in unstable carotid plaques. A potential role in acute plaque disruption. Stroke 31: 40-47, 2000.

127. Haffner SM, Greenberg AS, Weston WM, Chen H, Williams K and Freed MI: Effect of rosiglitazone treatment on nontraditional markers of cardiovascular disease in patients with type 2 diabetes mellitus. Circulation 106: 679-684, 2002.

128. Marx N, Froehlich J, Siam L, et al: Antidiabetic PPAR gammaactivator rosiglitazone reduces MMP-9 serum levels in type 2 diabetic patients with coronary artery disease. Arterioscler Thromb Vasc Biol 23: 283-288, 2003.
129. Portik-Dobos V, Anstadt MP, Hutchinson J, Bannan M and Ergul A: Evidence for a matrix metalloproteinase induction/ activation system in arterial vasculature and decreased synthesis and activity in diabetes. Diabetes 51: 3063-3068, 2002.

130. Signorelli SS, Malaponte G, Libra M, et al: Plasma levels and zymographic activities of matrix metalloproteinases 2 and 9 in type II diabetics with peripheral arterial disease. Vasc Med 10: $1-6,2005$

131. Adam DJ and Bradbury AW: TASC II document on the management of peripheral arterial disease. Eur J Vasc Endovasc Surg 33: 1-2, 2007. 